\title{
Prezados Editores da Revista Varia História,
}

Com grande surpresa, constatei, recentemente, que um artigo de autoria da Profa Dra. Marilda Santana da Silva, publicado nessa revista, em 2005, mais especificamente no número 33, é plágio de parte de minha dissertação de mestrado, "Filhos das Minas, americanos e portugueses: Identidades Coletivas na Capitania das Minas Gerais (1763-1792)", defendida em 2001, na Universidade de São Paulo, sob a orientação do Prof. Dr. István J ancsó. Das seis páginas que compõem o referido artigo, cinco constituem transcrições literais de idéias e palavras que podem ser encontradas nos capítulos 2 e 3 de minha dissertação. Frases e parágrafos são transcritos na íntegra, sem a preocupação em fazer uso de aspas nem, tampouco, em citar meu trabalho em nota de rodapé, práticas recomendadas tanto pelo Direito como pela Ética.

Nesse artigo, intitulado "O Senado da Câmara de Vila Rica e sua relação política com a Coroa Portuguesa na segunda metade do século XVIII", Marilda Silva versa sobre o posicionamento dos camaristas em relação às diretrizes metropolitanas no que se refere à crise aurífera. Tema esse que trabalhei nos citados capítulos, em especial no terceiro, tendo para tanto consultado fontes primárias no Instituto Histórico e Geográfico Brasileiro, no Rio de J aneiro. Trata-se das representações das câmaras mineiras no período de 1763-1792, depositadas no Arquivo Histórico Ultramarino que, à época de minha pesquisa, já haviam sido digitalizados pelo Projeto Resgate, embora os CD-rom não estivessem tão facilmente disponíveis, como hoje. Foi por essa razão que necessitei deslocar-me àquela cidade para realizar a leitura dos documentos. Se entro em detalhes quanto à documentação utilizada em meu trabalho, não é só para mostrar que a consulta que fiz da mesma demandou esforço físico, intelectual e financeiro. Na verdade, pretendo apenas deixar evidente que Marilda Silva plagiou páginas em que transcrevo e analiso fontes manuscritas, transcrevendo inclusive as notas de rodapé, dando a entender, portanto, que ela própria as teria consultado.

Estou ciente que a Revista não é responsável por este comportamento que agora torno público. Sei inclusive da preocupação do Conselho Editorial em se precaver contra situações desta natureza, submetendo todos os artigos que lhe são entregues para publicação à apreciação de dois pareceristas, como é de praxe. Infelizmente, esses não conheciam a minha dissertação, que não foi publicada, e ainda que a conhecessem não poderiam necessariamente saber que o artigo em questão não é da autoria de quem acreditou que poderia se passar por autora.

Esse tipo de comportamento antiético cometido pela Profa. Marilda Santana da Silva, infelizmente, não pode ser de todo evitado e é de sua única responsabilidade. Mas contra ele devemos nos precaver e posicionar 
quando por ventura vierem a ocorrer, não obstante os olhos atentos de pareceristas, bancas examinadoras e também orientadores. Como professora do ensino superior sei o quanto o plágio tem se constituído em prática recorrente entre os alunos. A facilidade com que têm acesso à internet explica em parte essa lamentável atitude que por vezes é tomada por aqueles que se esquecem que a produção histórica não depende unicamente de pesquisas bibliográficas e/ou documentais e da eleição de pressupostos teórico-metodológicos. Historiadores, como qualquer outro profissional, devem se comprometer em seguir uma conduta ética e os professores, cada vez mais, devem ensinar a seus alunos no que ela consiste. Neste sentido, é lamentável que o plágio aqui relatado tenha sido cometido por uma pesquisadora que hoje pertence ao corpo docente de uma Instituição de ensino superior.

Ao que parece, eu não sou a única a entender que tal situação é realmente grave. Os Editores desta Revista, ao me comunicarem, em janeiro de 2008, que me concederiam este espaço, demonstram que compartilham de minha posição e que desejam remediar um erro. A mesma indignação demonstrou o Reitor da Universidade de Campinas (UNICAMP) quando Ihe comuniquei que Marilda Silva plagiou igualmente parte de minha dissertação em sua tese de doutorado, "Poderes Locais em Minas Gerais Setecentista: A Representatividade do Senado da Câmara de Vila Rica (1760-1808)", defendida em 16 de maio 2003, no Departamento de História dessa renomada Universidade. Também nesse trabalho, em especial nos itens 3.2 e 3.3, constata-se a transcrição literal de minhas palavras, sem qualquer menção à autoria. A propósito, minha Dissertação de Mestrado só é mencionada ao final, nas referências bibliográficas. Nessa Universidade, uma Comissão já foi formada para averiguar a minha denúncia, à qual, em novembro passado, prestei esclarecimentos pessoalmente.

Sem dúvida alguma, a oportunidade que a Revista Varia História agora me concede atende as minhas expectativas e demonstra que, de alguma forma, as nossas Editoras estão preparadas para acolherem os que se sentem lesados. Como doutoranda do Departamento de História da Universidade de Brasília, gostaria de ter a certeza de que o saber que produzo, independentemente da minha escolha em publicá-lo ou não, a mim pertence, embora, evidentemente, tenha interesse em difundi-lo. Creio que se um dia tivermos alguma dúvida em relação a isso, a seriedade de nossas Instituições estará comprometida e completamente infundado o esforço intelectual próprio do trabalho dos verdadeiros historiadores.

Atenciosamente,

Roberta Stumpf

Lisboa, 07 de março de 2008. 